\title{
Clauson Kaas Pyrrole Synthesis Catalyzed by Acidic Ionic Liquid under Microwave Irradiation
}

\author{
Feray Aydogan and Cigdem Yolacan \\ Department of Chemistry, Yildiz Technical University, Davutpasa Campus, Esenler, 34010 Istanbul, Turkey \\ Correspondence should be addressed to Feray Aydogan; feray_aydogan@yahoo.com
}

Received 8 May 2013; Accepted 17 June 2013

Academic Editor: Ahmad Sazali Hamzah

Copyright (C) 2013 F. Aydogan and C. Yolacan. This is an open access article distributed under the Creative Commons Attribution License, which permits unrestricted use, distribution, and reproduction in any medium, provided the original work is properly cited.

\begin{abstract}
A new procedure to synthesize the $\mathrm{N}$-substituted pyrrole derivatives by Clauson Kaas reaction catalyzed by acidic ionic liquid under microwave irradiation was developed. This procedure provides several advantages such as high yield, clean product formation, and short reaction time.
\end{abstract}

Dedicated to the memory of Professor Ayhan S. Demir

\section{Introduction}

Pyrrole derivatives have great importance in organic chemistry, because they are present in many compounds which were natural, medicinal, and agricultural products and semiconductor polymers [1-3]. They are also very useful starting materials for biologically important compounds such as indolizidine alkaloids, bicyclic lactams, and unsaturated $\gamma$ lactams [4-7]. Various pyrrole syntheses have been reported in the literature [8-15]. One of these methods is Clauson Kaas pyrrole synthesis which uses 2,5-dimethoxytetrahydrofuran as four-carbon source. Although this reaction provides an important and useful way for synthesis of $\mathrm{N}$-substituted pyrroles, the necessity of high temperature and acidic conditions is resulted by the decomposition of product so low yields and difficult product separation are the main problems with this method [16, 17]. To overcome the problems with classical Clauson Kaas reaction, new synthetic methods such as using two phase system [16], initial aqueous hydrolysis of 2,5-dimethoxytetrahydrofuran [17], and using acetic acid, water, or sodium acetate buffer under microwave irradiation [18] and new catalysts [19-21] have been still developed successfully.

Using microwaves for carrying out reactions is advantageous for the synthesis of numerous types of compound.
The most important improvements with this technique are reduced reaction time, cleaner reactions due to fewer side reactions, and the use of minimal quantities of solvent [22, 23]. So, microwave-assisted synthesis is more economical and environmentally friendly method.

Ionic liquids (ILs) have been widely used in organic reactions as solvent due to their advantages such as negligible vapor pressure, variable polarity, and good solvating ability [24-26]. Recently, they have also attracted the researchers' attention due to their significant role in organic reactions as catalyst [27-32]. After the first use of imidazolium chloroaluminate as catalyst in Friedel-Crafts acylations [33], various ionic liquids have been developed and used in many types of organic reactions as catalyst. Many Lewis acidic and Bronsted acidic ionic liquids have been successfully used as acid catalysts in organic synthesis with advantages such as solvent-free reaction conditions, easy product separation, and recycling [34-39]. As far as we know, acidic ionic liquids have not been used to promote Clauson Kaas reaction, and only a few methods have been developed for this reaction under microwave irradiation $[18,40,41]$. So, we wish to report here the clean, short time synthesis of $\mathrm{N}$-substituted pyrrole derivatives by the Clauson Kaas reaction catalyzed by acidic ionic liquid, 1-hexyl-3-methylimidazolium hydrogen sulfate ([hmim] $\left.\left[\mathrm{HSO}_{4}\right]\right)$, under microwave irradiation. 
TABLE 1: Comparison of the catalytic activity of the catalysts.

\begin{tabular}{lcc}
\hline Catalyst & Time (min) & Yield (\%) \\
\hline $\mathrm{CH}_{3} \mathrm{CO}_{2} \mathrm{H}$ & 80 & 52 \\
{$[$ bmim $]\left[\mathrm{BF}_{4}\right]$} & 30 & 56 \\
{$[\mathrm{hmim}]\left[\mathrm{H}_{2} \mathrm{PO}_{4}\right]$} & 30 & 61 \\
{$[\mathrm{hmim}]\left[\mathrm{HSO}_{4}\right]^{\mathrm{a}}$} & 60 & 73 \\
{$[\mathrm{hmim}]\left[\mathrm{HSO}_{4}\right]$} & 4 & 85 \\
\hline
\end{tabular}

Without MW.

\section{Experimental}

All reagents were of commercial quality, and reagent quality solvents were used without further purification. IR spectra were determined on a Perkin Elmer, Spectrum One FTIR spectrometer. NMR spectra were recorded on Mercury VX-400 MHz and Bruker Avance III $500 \mathrm{MHz}$ spectrometer. Chemical shifts $\delta$ are reported in ppm relative to $\mathrm{CDCl}_{3}$ $\left({ }^{1} \mathrm{H}: \delta=7.27\right)$ and TMS as internal standard. Column chromatography was conducted on silica gel $60(40-63 \mu \mathrm{M})$. TLC was carried out on aluminum sheets precoated with silica gel $60 \mathrm{~F}_{254}$ (Merck). Elemental analysis was carried out on Thermo Flash EA 1112 series apparatus. Optical rotations were measured with Bellingham Stanley ADP-410 Polarimeter. Microwave-assisted reactions were carried out on an Arcelik MD 554 household oven.

2.1. General Procedure for Clauson Kaas Reaction. Amine (1 mmol) was added to 2,5-dimethoxytetrahydrofuran $(1 \mathrm{mmol}$ or $2 \mathrm{mmol}$ for amine $2 \mathrm{~b})$ in $[\mathrm{hmim}]\left[\mathrm{HSO}_{4}\right]$ $(1 \mathrm{mmol})$ and mixed thoroughly. The mixture was then exposed to microwave irradiation $(90 \mathrm{~W})$ for a period of time enough to complete the reaction. The reaction mixture was dissolved in water, and the product was extracted with diethyl ether $(3 \times 5 \mathrm{~mL})$, and the combined organic phases were dried over $\mathrm{MgSO}_{4}$. The crude product obtained after evaporation of the solvent was purified by column chromatography over silica gel (EtOAc: hexane $1: 2,1: 6$, or $1: 10)$.

2.1.1. (S)-1-(1-Phenylethyl)-1H-pyrrole (S)-3a. Colorless liquid (85\% yield). $[\alpha]_{D}^{20}=+6.6$; Lit. $+6.8[42]$ (c 2.7, $\left.\mathrm{CHCl}_{3}\right)$; IR (neat): $v 3027,2965,1603$, and $1377 \mathrm{~cm}^{-1} ;{ }^{1} \mathrm{H} \mathrm{NMR}(400 \mathrm{MHz}$, $\left.\mathrm{CDCl}_{3}\right): \delta 1.75\left(\mathrm{~d}, J=7.02 \mathrm{~Hz}, 3 \mathrm{H}, \mathrm{CH}_{3}\right), 5.20(\mathrm{q}, J=7.02 \mathrm{~Hz}$, $1 \mathrm{H}, \mathrm{N}-\mathrm{CH}), 6.11$ (brs, $2 \mathrm{H},=\mathrm{CH}), 6.68$ (brs, $2 \mathrm{H},=\mathrm{CH}), 7.01$ (d, $J=7.80 \mathrm{~Hz}, 2 \mathrm{H}, \mathrm{ArH})$, and $7.14(\mathrm{~m}, 3 \mathrm{H}, \mathrm{ArH})$. Anal. Calcd for $\mathrm{C}_{12} \mathrm{H}_{13} \mathrm{~N}$ (171.24): C, 84.17; H, 7.65; N, 8.18. Found: C, 84.22; $\mathrm{H}, 7.61 ; \mathrm{N}, 8.15$.

2.1.2. 1-(4-(1H-Pyrrol-1-yl)butyl)-1H-pyrrole 3b. Colorless oil (91\% yield). IR (neat): $v$ 3098, 2929, 2872, 1498, 1279, and $1087 \mathrm{~cm}^{-1} ;{ }^{1} \mathrm{H}$ NMR $\left(400 \mathrm{MHz} \mathrm{CDCl}_{3}\right): \delta 1.75\left(\mathrm{~m}, 4 \mathrm{H}, \mathrm{CH}_{2}\right)$, $3.85\left(\mathrm{t}, J=6.64 \mathrm{~Hz}, 4 \mathrm{H}, \mathrm{CH}_{2}\right), 6.15$ (apparent t, $J=1.95$, $1.95 \mathrm{~Hz}, 4 \mathrm{H},=\mathrm{CH}$ ), and 6.63 (apparent $\mathrm{t}, J=2.34,1.95 \mathrm{~Hz}$, $4 \mathrm{H},=\mathrm{CH})$. Anal. Calcd for $\mathrm{C}_{12} \mathrm{H}_{16} \mathrm{~N}_{2}$ (188.13): C, 76.55; $\mathrm{H}$, 8.57; N, 14.88. Found: C, 76.49; H, 8.58; N, 14.86.
2.1.3. (R)-Methyl 2-(1H-Pyrrol-1-yl)propanoate (R)-3c. Colorless oil $(73 \%$ yield $) .[\alpha]_{D}^{20}=+12.7$; Lit. +12.83 [42] (c 1.1, $\mathrm{CHCl}_{3}$ ); IR (neat): $v$ 3102, 2992, 2954, 1747, 1378, and $1282 \mathrm{~cm}^{-1} ;{ }^{1} \mathrm{H}$ NMR $\left(500 \mathrm{MHz}, \mathrm{CDCl}_{3}\right): \delta 1.65(\mathrm{~d}, \mathrm{~J}=$ $7.33 \mathrm{~Hz}, 3 \mathrm{H}, \mathrm{CH}_{3}$ ), $3.64\left(\mathrm{~s}, 3 \mathrm{H}, \mathrm{OCH}_{3}\right), 4.69$ (q, $J=7.33 \mathrm{~Hz}$, $1 \mathrm{H}, \mathrm{N}-\mathrm{CH}), 6.11$ (apparent $\mathrm{t}, J=2.44,1.96 \mathrm{~Hz}, 2 \mathrm{H},=\mathrm{CH}$ ), and 6.67 (apparent t, $J=2.44,1.95 \mathrm{~Hz}, 2 \mathrm{H},=\mathrm{CH}$ ). Anal. Calcd for $\mathrm{C}_{8} \mathrm{H}_{11} \mathrm{NO}_{2}$ (153.18): C, 62.73; H, 7.24; N, 9.14. Found: C, 62.76; $\mathrm{H}, 7.21 ; \mathrm{N}, 9.15$.

2.1.4. (S)-Methyl 3-Methyl-2-(1H-pyrrol-1-yl)butanoate (S)-3d. Colorless oil (69\% yield). $[\alpha]_{D}^{20}=-2.7$; Lit. -2.8 [42] (c 4.2, $\mathrm{CHCl}_{3}$ ); IR (neat): $\nu 3055,2986,1727,1372$, and $1285 \mathrm{~cm}^{-1} ;{ }^{1} \mathrm{H}$ $\operatorname{NMR}\left(400 \mathrm{MHz} \mathrm{CDCl}_{3}\right): \delta 0.67\left(\mathrm{~d}, \mathrm{~J}=6.65 \mathrm{~Hz}, 3 \mathrm{H}, \mathrm{CH}_{3}\right)$, $0.91\left(\mathrm{~d}, J=6.65 \mathrm{~Hz}, 3 \mathrm{H}, \mathrm{CH}_{3}\right), 2.32(\mathrm{~m}, 1 \mathrm{H}, \mathrm{CH}), 3.63(\mathrm{~s}, 3 \mathrm{H}$, $\left.\mathrm{CH}_{3}\right), 4.00(\mathrm{~d}, \mathrm{~J}=10.23 \mathrm{~Hz}, 1 \mathrm{H}, \mathrm{N}-\mathrm{CH}), 6.02$ (brs, $\left.2 \mathrm{H},=\mathrm{CH}\right)$, and 6.63 (brs, $2 \mathrm{H},=\mathrm{CH}$ ). Anal. Calcd for $\mathrm{C}_{10} \mathrm{H}_{15} \mathrm{NO}_{2}$ (181.23): C, 66.27; H, 8.34; N, 7.73. Found: C, 66.28; H, 8.40; N, 7.69.

2.1.5. (S)-2-(1H-Pyrrol-1-yl)propan-1-ol (S)-3e. Colorless oil (89\% yield). $[\alpha]_{D}^{20}=+8.3$; Lit. +8.25 [42] (c 2.2, $\mathrm{CHCl}_{3}$ ); IR (neat): $\nu 3524,3098,2982,1558,1378$, and $1280 \mathrm{~cm}^{-1} ;{ }^{1} \mathrm{H}$ NMR $\left(400 \mathrm{MHz} \mathrm{CDCl}_{3}\right): \delta 1.37\left(\mathrm{~d}, J=7.02 \mathrm{~Hz}, 3 \mathrm{H}, \mathrm{CH}_{3}\right), 1.63$ (brs, $1 \mathrm{H}, \mathrm{OH}), 3.59$ (m, 2H, $\left.\mathrm{CH}_{2}\right), 4.09(\mathrm{~m}, 1 \mathrm{H}, \mathrm{N}-\mathrm{CH}), 6.10$ (brs, $2 \mathrm{H},=\mathrm{CH}$ ), and 6.67 (brs, $2 \mathrm{H},=\mathrm{CH}$ ). Anal. Calcd for $\mathrm{C}_{7} \mathrm{H}_{11} \mathrm{NO}$ (125.17): C, 67.17; H, 8.86; N, 11.19. Found: C, 67.21; $\mathrm{H}, 8.84 ; \mathrm{N}, 11.16$.

2.1.6. (R)-2-(1H-Pyrrol-1-yl)butan-1-ol (R)-3f. Colorless oil (91\% yield). $[\alpha]_{D}^{20}=+14.3$; Lit. +14.3 [ 42$]$ ( $c 0.4, \mathrm{CHCl}_{3}$ ); IR (neat): $\nu 3517,3048,2998,1602,1376$, and $1282 \mathrm{~cm}^{-1} ;{ }^{1} \mathrm{H}$ NMR $\left(400 \mathrm{MHz}_{\mathrm{CDCl}}\right): \delta 0.85\left(\mathrm{t}, J=7.41 \mathrm{~Hz}, 3 \mathrm{H}, \mathrm{CH}_{3}\right), 1.68$ (brs, $1 \mathrm{H}, \mathrm{OH}), 1.77\left(\mathrm{~m}, 2 \mathrm{H}, \mathrm{CH}_{2}\right), 3.73\left(\mathrm{~m}, 2 \mathrm{H}, \mathrm{CH}_{2}\right), 3.85(\mathrm{~m}, 1 \mathrm{H}$, $\mathrm{N}-\mathrm{CH}$ ), 6.18 (apparent $\mathrm{t}, J=2.34,1.95 \mathrm{~Hz}, 2 \mathrm{H},=\mathrm{CH}$ ), and 6.70 (apparent t, $J=2.34,1.95 \mathrm{~Hz}, 2 \mathrm{H},=\mathrm{CH}$ ). Anal. Calcd for $\mathrm{C}_{8} \mathrm{H}_{13} \mathrm{NO}$ (139.19): C, 69.03; H, 9.41; N, 10.06. Found: C, 69.01; $\mathrm{H}, 9.42 ; \mathrm{N}, 9.96$.

2.1.7. (1R, 2S)-1-Phenyl-2-(1H-pyrrol-1-yl)propan-1-ol (1R, 2S)3g. Yellow oil (83\% yield). $[\alpha]_{D}^{20}=+26.6$; Lit. +26.8 [42] (c 3.6, $\mathrm{CHCl}_{3}$ ); IR (neat): $v$ 3523, 3054, 2994, 1605, 1376, and $1283 \mathrm{~cm}^{-1} ;{ }^{1} \mathrm{H}$ NMR $\left(400 \mathrm{MHz}, \mathrm{CDCl}_{3}\right): \delta 1.33(\mathrm{~d}, J=$ $7.00 \mathrm{~Hz}, 3 \mathrm{H}, \mathrm{CH}_{3}$ ), 2.11 (brs, $\left.1 \mathrm{H}, \mathrm{OH}\right), 4.08$ (m, $1 \mathrm{H}, \mathrm{N}-\mathrm{CH}$ ), $4.61(\mathrm{~d}, J=4.68 \mathrm{~Hz}, 1 \mathrm{H}, \mathrm{O}-\mathrm{CH}), 5.94$ (brs, $2 \mathrm{H},=\mathrm{CH}), 6.47$ (brs, $2 \mathrm{H},=\mathrm{CH}), 7.04(\mathrm{~d}, J=7.60 \mathrm{~Hz}, 2 \mathrm{H}, \mathrm{ArH})$, and $7.16(\mathrm{~m}$, $3 \mathrm{H}, \mathrm{ArH}$ ). Anal. Calcd for $\mathrm{C}_{13} \mathrm{H}_{15} \mathrm{NO}$ (201.26): C, 77.58; $\mathrm{H}$, 7.51; N, 6.96. Found: C, 77.51; H, 7.60; N, 7.01.

2.1.8. (1S, 2S)-1-Phenyl-2-(1H-pyrrol-1-yl)propane-1,3-diol (1S, $2 S)$-3h. Yellow oil (81\% yield). $[\alpha]_{D}^{20}=+93.2$; Lit. $+93.5[42]$ (c $0.5, \mathrm{CHCl}_{3}$ ); IR (neat): $v$ 3525, 3050, 1605, 1375, and $1284 \mathrm{~cm}^{-1} ;{ }^{1} \mathrm{H} \mathrm{NMR}\left(400 \mathrm{MHz}, \mathrm{CDCl}_{3}\right): \delta 2.00$ (brs, $\left.1 \mathrm{H}, \mathrm{OH}\right)$, 2.45 (brs, $1 \mathrm{H}, \mathrm{OH}), 3.72\left(\mathrm{~m}, 2 \mathrm{H}, \mathrm{CH}_{2}\right), 4.06$ (m, $\left.1 \mathrm{H}, \mathrm{N}-\mathrm{CH}\right)$, $4.92(\mathrm{~d}, J=6.6 \mathrm{~Hz}, 1 \mathrm{H}, \mathrm{O}-\mathrm{CH}), 6.15$ (apparent $\mathrm{t}, J=1.95$, $1.95 \mathrm{~Hz}, 2 \mathrm{H},=\mathrm{CH}$ ), 6.70 (apparent $\mathrm{t}, J=2.34,1.95 \mathrm{~Hz}, 2 \mathrm{H}$, $=\mathrm{CH}), 7.19(\mathrm{~m}, 2 \mathrm{H}, \mathrm{ArH})$, and $7.31(\mathrm{~m}, 3 \mathrm{H}, \mathrm{ArH})$. Anal. Calcd 
TABLE 2: The synthesized pyrrole derivatives.

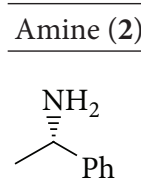

(S)-2a<smiles>NCCCCN</smiles>

$2 b$<smiles>CC(=O)[C@H](C)N</smiles>

(R)-2c<smiles>CC(=O)[C@H](N)C(C)C</smiles>

(S)-2d<smiles>C[C@H](N)CO</smiles>

(S) $-2 \mathrm{e}$<smiles>CC[C@H](N)CO</smiles>

(R)-2f<smiles>C[C@H](N)[C@H](O)c1ccccc1</smiles>

$(1 R, 2 S)-\mathbf{2 g}$<smiles>N[C@@H](CO)[C@H](O)c1ccccc1</smiles>

$(1 S, 2 S)-\mathbf{2 h}$<smiles>Cc1ccnc(N)n1</smiles>

$2 \mathrm{i}$

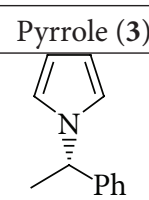

Reaction time (min)

4

85

(S)-3a [42]<smiles>c1ccn(CCCCn2cccc2)c1</smiles>

4

91

$3 \mathbf{b}[43]$<smiles>CC(=O)C(C)n1cccc1</smiles>

3

73

(R)-3c [42]<smiles>CC(=O)[C@H](C(C)C)n1cccc1</smiles>

3

69

(S)-3d [42]<smiles>C[C@H](CO)n1cccc1</smiles>

$(S)-3 \mathbf{e}[42]$<smiles>CC[C@H](CO)n1cccc1</smiles>

(R)-3f [42]<smiles>C[C@H]([C@H](O)c1ccccc1)n1cccc1</smiles>

(1R, 2S)-3g [42]<smiles>OC[C@@H](c1ccccc1)n1cccc1</smiles>

5

81

(1S, 2S)-3h [42]

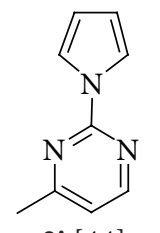


for $\mathrm{C}_{13} \mathrm{H}_{15} \mathrm{NO}_{2}$ (217.26): C, 71.87; H, 6.96; N, 6.45. Found: C, 71.82; H, 6.97; N, 6.41.

2.1.9. 1-(4-Methyl-2-pyrimidinyl)-1H-pyrrole 3i. White solid, mp. $44-45^{\circ} \mathrm{C}$; Lit. $44.5-46^{\circ} \mathrm{C}$ [44] (72\% yield). IR (neat): $v$ 2917, 1583, 1475, 1434, and $1384 \mathrm{~cm}^{-1} ;{ }^{1} \mathrm{H}$ NMR $(500 \mathrm{MHz}$, $\left.\mathrm{CDCl}_{3}\right): \delta 2.51\left(\mathrm{~s}, 3 \mathrm{H}, \mathrm{CH}_{3}\right), 6.32($ apparent $\mathrm{t}, J=2.25 \mathrm{~Hz}$, $2 \mathrm{H},=\mathrm{CH}), 6.90(\mathrm{~d}, J=5.00 \mathrm{~Hz}, 1 \mathrm{H}, \mathrm{ArH}), 7.79$ (apparent t, $J=2.25 \mathrm{~Hz}, 2 \mathrm{H},=\mathrm{CH})$, and $8.44(\mathrm{~d}, J=5.05 \mathrm{~Hz}, 1 \mathrm{H}, \mathrm{ArH})$. Anal. Calcd for $\mathrm{C}_{9} \mathrm{H}_{9} \mathrm{~N}_{3}$ (159.19): C, 67.90; H, 5.70; N, 26.40. Found: C, 67.86; H, 5.72; N, 26.41.

\section{Results and Discussion}

The acidic ionic liquid $[\mathrm{hmim}]\left[\mathrm{HSO}_{4}\right]$ was prepared under microwave irradiation starting from [hmim][Br] according to the literature procedure [45], and the spectral data of the compound were in accordance with the reported data [46]. We started the research with $(S)$-phenylethylamine as a representative reactant to see if the acidic IL would catalyze the Clauson Kaas reaction and to achieve optimum reaction conditions such as microwave irradiation power, IL amount, and the necessity of cosolvent such as diethyl ether, chloroform. It was found that the reaction was completed within $4 \mathrm{~min}$ in the presence of equimolar amount of acidic ionic liquid under solvent-free conditions without any decomposition of product. The reaction was also carried out without microwave irradiation by stirring the reaction mixture at room temperature. It was found that the reaction completed in 1 hour with the decomposition of small amount product.

The catalytic activity of $[\mathrm{hmim}]\left[\mathrm{HSO}_{4}\right]$ was compared with those of acetic acid, $[\mathrm{bmim}]\left[\mathrm{BF}_{4}\right]$, and $[\mathrm{hmim}]\left[\mathrm{H}_{2} \mathrm{PO}_{4}\right]$, which was prepared by the same procedure with $[\mathrm{hmim}]\left[\mathrm{HSO}_{4}\right]$, under the optimum conditions. As one can see from the results shown in the Table 1 , $[\mathrm{hmim}]\left[\mathrm{HSO}_{4}\right]$ was found to be best catalyst providing $85 \%$ yield of product.

In a typical reaction procedure, 2,5-dimethoxytetrahydrofuran ( $1 \mathrm{mmol})$, equimolar amount of amine, and [hmim] $\left[\mathrm{HSO}_{4}\right]$ were mixed, and the mixture was exposed to microwave irradiation $(90 \mathrm{~W})$ for a period of time enough to complete the reaction. The reaction mixture was dissolved in water, and the product was extracted with diethyl ether and purified by column chromatography. To check the reusability of the ionic liquid, water was removed from the aqueous layer under vacuum, and the residue was washed with diethyl ether and dried under vacuum. Decreasing in the yield of pyrrole was seen after recycling of ionic liquid. The main problem with the Clauson Kaas reaction is the decomposition of acid sensitive derivatives, especially derived from amino acids. Using this procedure, various amine compounds such as aliphatic amines, amino acid esters, amino alcohols, and heteroaromatic amine were converted to their pyrrole derivatives without any significant decomposition (Scheme 1) in $69-91 \%$ yield, as summarized in Table 2. Some of the amines were chiral, and any racemization was not observed with these amines. All of the pyrrole derivatives are known in the

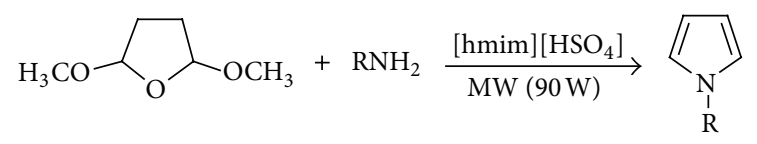

$(1)$

(2)

(3)

Scheme 1: The synthesis of $\mathrm{N}$-substituted pyrroles catalyzed by $[\mathrm{hmim}]\left[\mathrm{HSO}_{4}\right]$.

literature, and their spectroscopic data are in full agreement with their structures.

\section{Conclusion}

In conclusion, efficient synthesis of $\mathrm{N}$-substituted pyrrole derivatives has been achieved by Clauson Kaas reaction catalyzed by acidic ionic liquid under microwave irradiation. This new method provides a clean, fast, high yielded, environmentally friendly, and effective way to pyrroles without any significant decomposition of acid sensitive derivatives.

\section{References}

[1] R. Ragno, G. R. Marshall, R. Di Santo et al., "Antimycobacterial pyrroles: synthesis, anti-Mycobacterium tuberculosis activity and QSAR studies," Bioorganic and Medicinal Chemistry, vol. 8, no. 6, pp. 1423-1432, 2000.

[2] R. K. Dieter and H. Yu, "A facile synthesis of polysubstituted pyrroles," Organic Letters, vol. 2, no. 15, pp. 2283-2286, 2000.

[3] C. Franc, F. Denonne, C. Cuisinier, and L. Ghosez, "A general synthesis of 2-formyl-3-arylpyrroles," Tetrahedron Letters, vol. 40, no. 24, pp. 4555-4558, 1999.

[4] J. Liu, Q. Yang, T. C. W. Mak, and H. N. C. Wong, "Highly regioselective synthesis of 2,3,4-trisubstituted $1 H$-pyrroles: a formal total synthesis of lukianol A," Journal of Organic Chemistry, vol. 65 , no. 12 , pp. 3587-3595, 2000.

[5] C. W. Jefford, K. Sienkiewicz, and S. R. Thornton, "Short, enantiospecific synthesese of indolizidines 209B and 209D, and piclavine A from diethyl-L-glutamate," Helvetica Chimica Acta, vol. 78, no. 6, pp. 1511-1524, 1995.

[6] R. I. J. Amos, B. S. Gourlay, P. P. Molesworth, J. A. Smith, and O. R. Sprod, "Annulation of pyrrole: application to the synthesis of indolizidine alkaloids," Tetrahedron, vol. 61, no. 34, pp. 82268230, 2005.

[7] C. W. Jefford, Q. Tang, and A. Zaslona, "Short, enantiogenic syntheses of (-)-indolizidine 167b and (+)-monomorine," Journal of the American Chemical Society, vol. 113, no. 9, pp. 3513-3518, 1991.

[8] V. Estevez, M. Villacampa, and J. C. Menedez, "Multicomponent reactions for the synthesis of pyrroles," Chemical Society Reviews, vol. 39, no. 11, pp. 4402-4421, 2010.

[9] H. Valizadeh, M. M. Heravi, and M. Amiri, "Conventional and microwave-assisted facile one-pot synthesis of $N$-substituted pyrrole-2,3,4,5-tetracarboxylates under neat conditions," Synthetic Communications, vol. 40, no. 24, pp. 3699-3706, 2010.

[10] O. A. Attanasi, G. Favi, F. Mantellini, G. Moscatelli, and S. Santeusanio, "Synthesis of functionalized pyrroles via catalystand solvent-free sequential three-component enamine-azenone annulation," Journal of Organic Chemistry, vol. 76, no. 8, pp. 2860-2866, 2011. 
[11] F. J. Leeper and J. M. Kelly, "Synthesis of 3,4-disubstituted pyrroles. A review," Organic Preparations and Procedures International, vol. 45, no. 3, pp. 171-210, 2013.

[12] B. Li, N. Wang, Y. Liang, S. Xu, and B. Wang, "Ruteniumcatalyzed pyrrole synthesis via oxidative annulation of enamides and alkynes," Organic Letters, vol. 15, no. 1, pp. 136-139, 2013.

[13] R. J. Billedeau, K. R. Klein, D. Kaplan, and Y. Lou, "A new pyrrole synthesis via silver(I)-catalyzed cycloaddition of vinylogous dazoester and nitrile," Organic Letters, vol. 15, no. 7, pp. 14211423, 2013.

[14] D. G. Dunford, D. W. Knight, and R. C. Wheeler, "An efficient copper-ctalysed pyrrole synthesis," ARKIVOC, vol. 2012, no. 7, pp. 253-273, 2012.

[15] F. Aydogan and A. S. Demir, "Clean and efficient microwavesolvent-free conversion of homochiral amines, $\alpha$-amino alcohols and $\alpha$-amino acids to their chiral 2 -substituted pyrrole derivatives," Tetrahedron, vol. 61, no. 12, pp. 3019-3023, 2005.

[16] C. W. Jefford, F. De Villedon De Naide, and K. Sienkiewicz, "The synthesis of chiral 1-(1H-pyrrole) derivatives," Tetrahedron Asymmetry, vol. 7, no. 4, pp. 1069-1076, 1996.

[17] B. S. Gourlay, P. P. Molesworth, J. H. Ryan, and J. A. Smith, "A new and high yielding synthesis of unstable pyrroles via a modified Clauson-Kaas reaction," Tetrahedron Letters, vol. 47, no. 5, pp. 799-801, 2006.

[18] K. C. Miles, S. M. Mays, B. K. Southerland, T. J. Auvil, and D. M. Ketcha, "The Clauson-Kaas pyrrole synthesis under microwave irradiation," Arkivoc, vol. 2009, no. 14, pp. 181-190, 2009.

[19] F. P. Ma, P. H. Li, B. L. Li et al., "A recyclable magnetic nanoparticles supported antimony catalyst for the synthesis of $N$-substituted pyrroles in water," Applied Catalysis A, vol. 457, pp. 34-41, 2013.

[20] X. Zhang and J. Shi, "Unique chemoselective Clauson-Kass reaction of substituted aniline catalyzed by $\mathrm{MgI}_{2}$ etherate," Tetrahedron, vol. 67, no. 5, pp. 898-903, 2011.

[21] V. Polshettiwar, B. Baruwati, and R. S. Varma, "Magnetic nanoparticle-supported glutathione: a conceptually sustainable organocatalyst," Chemical Communications, no. 14, pp. 18371839, 2009.

[22] L. Perreux and A. Loupy, "A tentative rationalization of microwave effects in organic synthesis according to the reaction medium, and mechanistic considerations," Tetrahedron, vol. 57, no. 45, pp. 9199-9223, 2001.

[23] P. Lidström, J. Tierney, B. Wathey, and J. Westman, "Microwave assisted organic synthesis-a review," Tetrahedron, vol. 57, no. 45, pp. 9225-9283, 2001.

[24] S. Suresh and J. S. Sandhu, "Recent advances in ionic liquids: green unconventional solvents of this century: part I," Green Chemistry Letters and Reviews, vol. 4, no. 4, pp. 289-310, 2011.

[25] T. Welton, "Room-temperature ionic liquids. Solvents for synthesis and catalysis," Chemical Reviews, vol. 99, no. 8, pp. 20712083, 1999.

[26] H. Olivier-Bourbigou and L. Magna, "Ionic liquids: perspectives for organic and catalytic reactions," Journal of Molecular Catalysis A, vol. 182-183, pp. 419-437, 2002.

[27] S. Toma, M. Meciarova, and R. Sebesta, "Are ionic liquids suitable media for organocatalytic reactions?" European Journal of Organic Chemistry, no. 3, pp. 321-327, 2009.

[28] A. D. Sawant, D. G. Raut, N. B. Darvatkar, and M. M. Salunkhe, "Recent developments of task-specific ionic liquids in organic synthesis," Green Chemistry Letters and Reviews, vol. 4, no. 1, pp. 41-54, 2011.
[29] A. G. Ying, L. Liu, G. F. Wu, G. Chen, X. Z. Chen, and W. D. Ye, "Aza-Michael addition of aliphatic or aromatic amines to $\alpha, \beta$-unsaturated compounds catalyzed by a DBU-derived ionic liquid under solvent-free conditions," Tetrahedron Letters, vol. 50, no. 14, pp. 1653-1657, 2009.

[30] D. Chaturvedi, "Recent developments on task specific ionic liquids," Current Organic Chemistry, vol. 15, no. 8, pp. 1239-1248, 2011.

[31] S. Narayanaperumal, R. Cesar da Silva, K. S. Feu, A. Fernández de la Torre, A. G. Correa, and M. W. Paixao, "Basicfunctionalized recyclable ionic liquid catalyst: a solvent-free approach for Michael addition of 1,3-dicarbonyl compounds to nitroalkenes under ultrasound irradiation," Ultrasonics Sonochemistry, vol. 20, no. 3, pp. 793-798, 2013.

[32] A. Mulik, D. Chandam, P. Patil, D. Patil, S. Jagdale, and M. Deshmukh, "Proficient synthesis of quinoxaline and phthalazinetrione derivatives using $\left[\mathrm{C}_{8}\right.$ dabco $] \mathrm{Br}$ ionic liquid as catalyst in aqueous media," Journal of Molecular Liquids, vol. 179, pp. 104109, 2013.

[33] J. A. Boon, J. A. Levisky, J. L. Pflug, and J. S. Wilkes, "FriedelCrafts reactions in ambient-temperature molten salts," Journal of Organic Chemistry, vol. 51, no. 4, pp. 480-483, 1986.

[34] A. R. Hajipour and F. Rafiee, "Acidic bronsted ionic liquids," Organic Preparations and Procedures International, vol. 42, no. 4, pp. 285-362, 2010.

[35] R. Srivastava, "Assessment of the catalytic activities of novel brönsted acidic ionic liquid catalysts," Catalysis Letters, vol. 139, no. 1-2, pp. 17-25, 2010.

[36] S. Sajjadifar, E. R. Nezhad, and G. Darvishi, "1-Methyl-3(2-(sulfooxy)ethyl)-1H-imidazol-3-ium chloride as a new and green ionic liquid catalyst for one-pot synthesis of dihydropyrimidinones under solvent-free conditions," Journal of Chemistry, vol. 2013, Article ID 834656, 6 pages, 2013.

[37] Z. S. Qureshi, K. M. Deshmukh, K. P. Dhake, and B. M. Bhanage, "Brønsted acidic ionic liquid: a simple, efficient and recyclable catalyst for regioselective alkylation of phenols and anti-Markovnikov addition of thiols to alkenes," RSC Advances, vol. 1, no. 6, pp. 1106-1112, 2011.

[38] X. Q. Chu, R. Jiang, Y. Fang et al., "Acidic-functionalized ionic liquid as an efficient, green, and metal-free catalyst for benzylation of sulfur, nitrogen, and carbon nucleophiles to benzylic alcohols," Tetrahedron, vol. 69, no. 3, pp. 1166-1174, 2013.

[39] H. R. Shaterian and K. Azizi, "Acidic ionic liquids catalyzed onepot, pseudo five-component, and diastereoselective synthesis of highly functionalized piperidine derivatives," Journal of Molecular Liquids, vol. 180, pp. 187-191, 2013.

[40] M. Abid, S. M. Landge, and B. Török, "An efficient and rapid synthesis of $N$-substituted pyrroles by microwave assisted solid acid catalysis," Organic Preparations and Procedures International, vol. 38, no. 5, pp. 495-500, 2006.

[41] C. C. Silveira, M. P. Fortes, and S. R. Mendes, "Cerium (III) chloride as a catalyst in the Clauson-Kaas reaction: synthesis and reactivity of N-Aryl-2-thiocyanatopyrroles," Current Organic Chemistry, vol. 16, no. 12, pp. 1540-1548, 2012.

[42] F. Aydogan, M. Basarir, C. Yolacan, and A. S. Demir, "New and clean synthesis of $\mathrm{N}$-substituted pyrroles under microwave irradiation," Tetrahedron, vol. 63, no. 39, pp. 9746-9750, 2007.

[43] N. D. Scott, "Production of N-alkyl pyrroles," 1949, US 2488336 19491115. 
[44] I. Becker, "Preparation of pyrrole and pyrrolidine derivatives of pyrimidine. 1-(2-Pyrimidinyl)pyrrole-an inhibitor of X. Phaseoli and X. Malvacearum," Journal of Heterocyclic Chemistry, vol. 41, no. 3, pp. 343-348, 2004.

[45] V. Singh, S. Kaur, V. Sapehiyia, J. Singh, and G. L. Kad, "Microwave accelerated preparation of $[\mathrm{bmim}]\left[\mathrm{HSO}_{4}\right]$ ionic liquid: an acid catalyst for improved synthesis of coumarins," Catalysis Communications, vol. 6, no. 1, pp. 57-60, 2005.

[46] J. Fraga-Dubreuil, K. Bourahla, M. Rahmouni, J. P. Bazureau, and J. Hamelin, "Catalysed esterifications in room temperature ionic liquids with acidic counteranion as recyclable reaction media," Catalysis Communications, vol. 3, no. 5, pp. 185-190, 2002. 

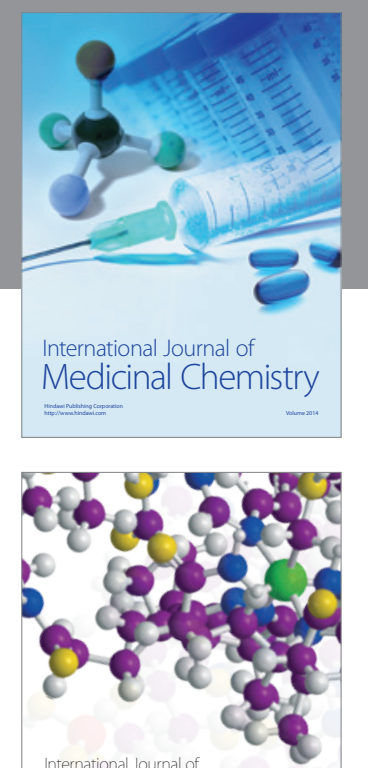

\section{Carbohydrate} Chemistry

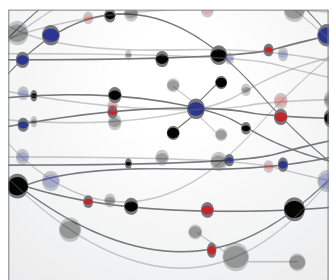

The Scientific World Journal
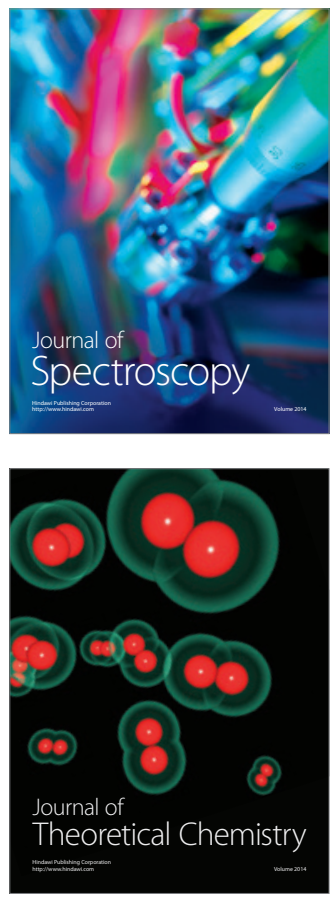
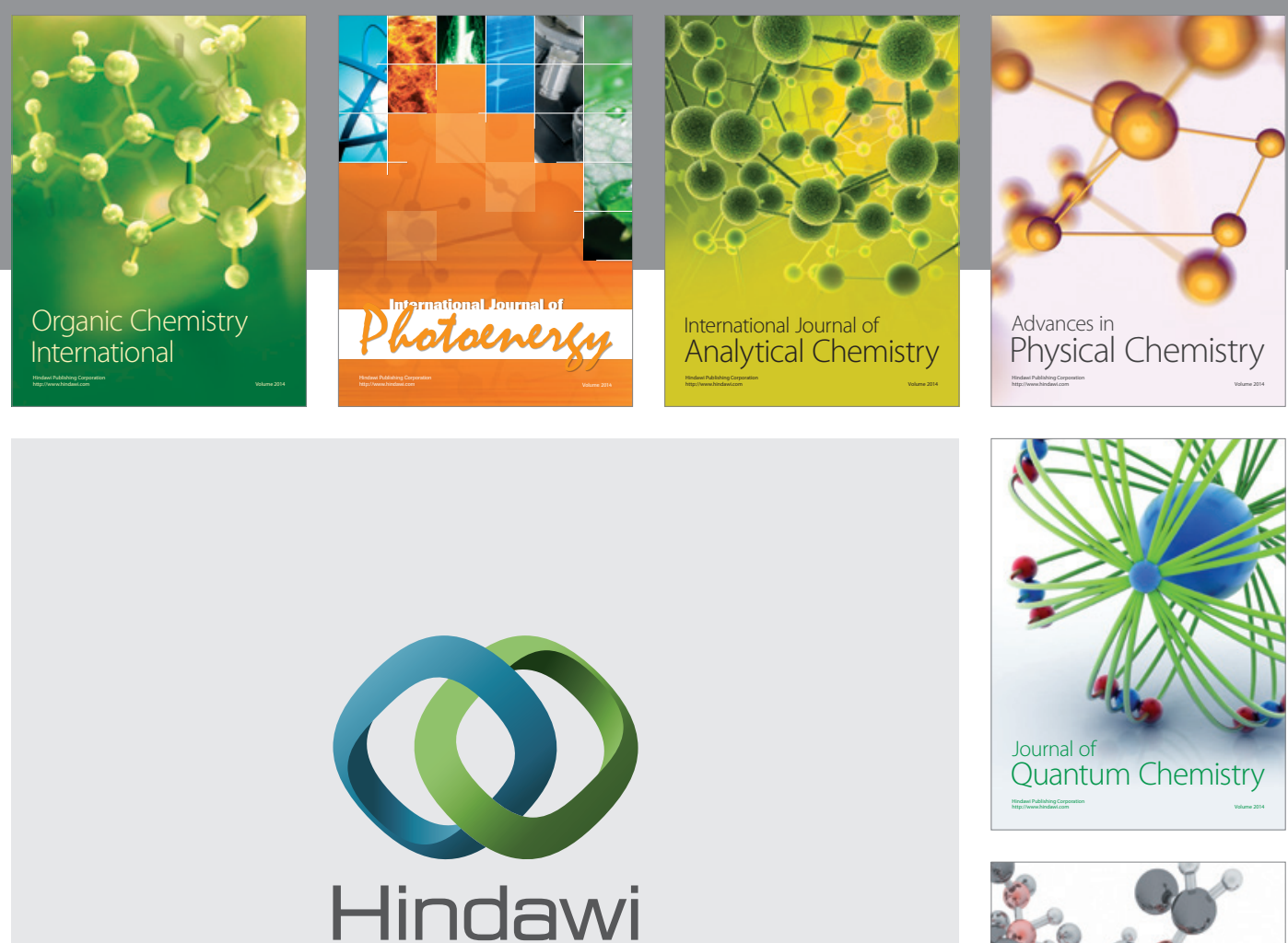

Submit your manuscripts at

http://www.hindawi.com

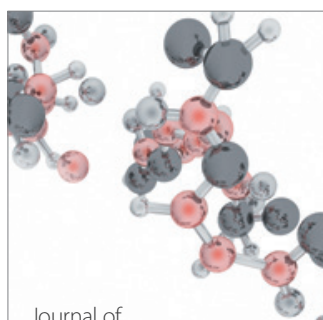

Analytical Methods

in Chemistry

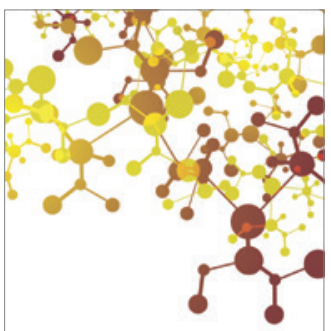

Journal of

Applied Chemistry

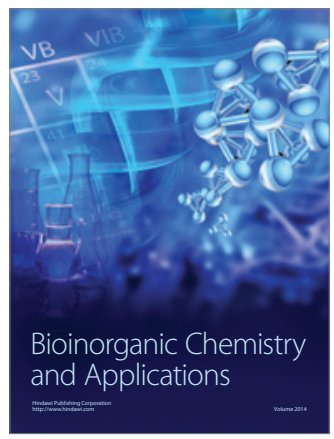

Inorganic Chemistry
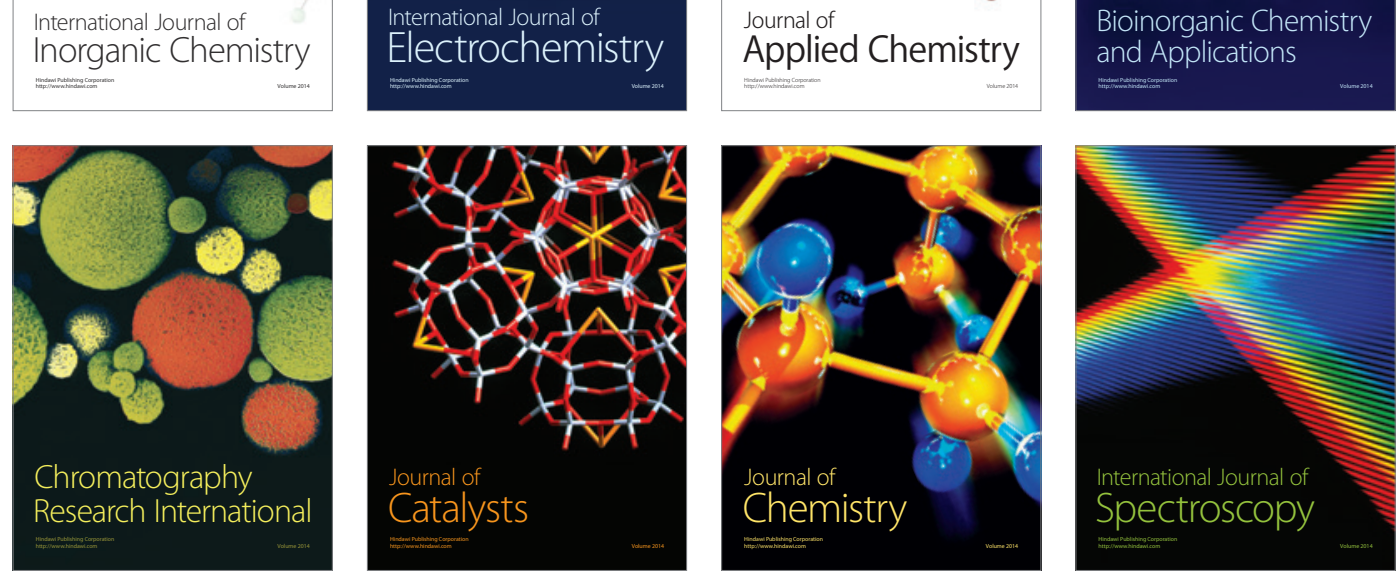